\title{
Tectonics of the Chęciny Anticline (Holy Cross Mts., central Poland) in the light of new cartographic data and calcite vein analysis (reply)
}

\author{
Edyta JUREWICZ ${ }^{1, *}$ and Urszula STĘPIEŃ ${ }^{2}$ \\ 1 Faculty of Geology, University of Warsaw, wirki i Wigury 93, 02-089 Warszawa, Poland \\ 2 Polish Geological Institute - National Research Institute, Rakowiecka 4, 00-975 Warszawa, Poland
}

$\frac{8}{2}$

Jurewicz E. and Stepień U. (2013) Tectonics of the Chęciny Anticline (Holy Cross Mts., central Poland) in the light of new cartographic data and calcite vein analysis (reply). Geological Quarterly, 57 (1): 181-186, doi: 10.7306/gq.1069

In our paper (Jurewicz and Stępień, 2012) we proposed a simple method for extension magnitude estimation and we demonstrated the presence of an anticline to the south of the Rzepka Syncline. Mastella et al. (2013) challenge our newly found outcrops of Cambrian rocks and their interpretation.

Cambrian rocks at point "B" (Jurewicz and Stępień 2012: fig. 2A), which could indicate the location of the anticline axis, were uncovered in earthworks excavated during the fencing-off of a gas station by the E7 motorway in 2006. Notwithstanding two tiny dip symbols pointing to south-dipping Devonian strata, can be seen in Czarnocki's (1938) map south of Rzepka with help of a magnifying glass. This map had been produced before stone began to be exploited in Korzecko Quarry at Rzepka Hill - thus when numerous Devonian exposure were scattered across the area. Both Mastella et al. (2013) and many others before them (e.g., Hakenberg, 1973; Konon, 2006; Jurewicz and Stępień, 2012) have not noticed these dip symbols on Czarnocki's (1938) map.

Another problem is a gap in Devonian outcrops between Rzepka and Sosnówka. Triassic outcrops shown on photographs in Mastella et al. (2013) indirectly point to the absence of Devonian, because the latter would form positive morphology. Those photos thus would support the idea that Triassic palaeomorphology has been uncovered, with Triassic filling natural depressions created due to e.g., underlying soft Cambrian rocks - a phenomenon commonly seen in this area. Moreover, Mastella et al. (2013) do not attempt to explain the presence of Cambrian rocks that they found (fig. 1C). $30-50 \mathrm{~cm}$ thick Cambrian regolith overlying weathered Triassic rocks and extending over several hundreds of square metres cannot be explained as glacial origin. We suggest that the reason is a periodically open fault fissure along which Cambrian could have flowed to the surface both in the past and at present. It may have pierced thin Buntsandstein deposits. In 2008 we were lucky enough to find exactly the place where this Cambrian

\footnotetext{
* Corresponding author: edyta.jurewicz@uw.edu.pl
}

Received: November 30, 2012; accepted: December 16, 2012; first published online: January 11, 2013 emerges at the surface. We are conscious that we have no final proof, but we do have a consistent hypothesis.

The answers to the remaining objections articulated in Mastella et al. (2013) have been organized by themes.

\section{DIAPIRIC FOLDING, STRATA ATTITUDES IN CHĘCINY ANTICLINE LIMBS AND THE CROSS-SECTION ACROSS THE CHECINY ANTICLINE}

It seems that the Chęciny Anticline, the limbs of which are made of 600 m thick (Hakenberg, 1973, 1974; Filonowicz and Lindner, 1986, 1987), Middle and Upper Devonian massive and reef, limestones and dolostones, mainly thick-bedded, suffered axis-parallel fracturing. This apparently caused both release of Cambrian deposits trapped in the anticline hinge and also allowed rainwater infiltration resulting in the swelling of clay minerals. The two phenomena provoked diapiric-like flow and shifting of mass from synclinal hinges towards the cores of the anticlines (see Stewart, 1996). Overturning of Devonian strata may be achieved only if fold limbs were strongly uplifted. When fold amplitude is sufficiently great (more than the thickness of fold limbs) strata may be the "fall over" (Fig. 1). As seen in the map and in the block diagram based on it, such a configuration is most easily achieved in up-thrown blocks, e.g. block 4 (Jurewicz and Stępień, 2012: figs. 2B and 4). Block 5 (Sosnówka) is located so close to Zegzela Hill, that it is difficult to say whether overturned strata are related to structural complications due to replacement of the Rzepka structure by reverse faults or whether they are due to diapiric flow. Mastella et al. (2013) show pictures of overturned strata in their figure $2 \mathrm{~A}-\mathrm{C}-$ which is inconsistent with what they show in the cross-section where they locate these pictures (Mastella et al., 2013: fig. 2D). They claim that pictured strata attitudes (overturned strata) are representative for the area depicted in the cross-section. However, both at Zamkowa and at Zelejowa hills normal strata attitudes predominate (e.g., Czarnocki, 1938; Kotański, 1959; Hakenberg, 1973). In order to be consistent with their model, one should draw Chęciny Anticline as a box-fold. We would also like to underline that the cross-section in figure $2 \mathrm{D}$ 

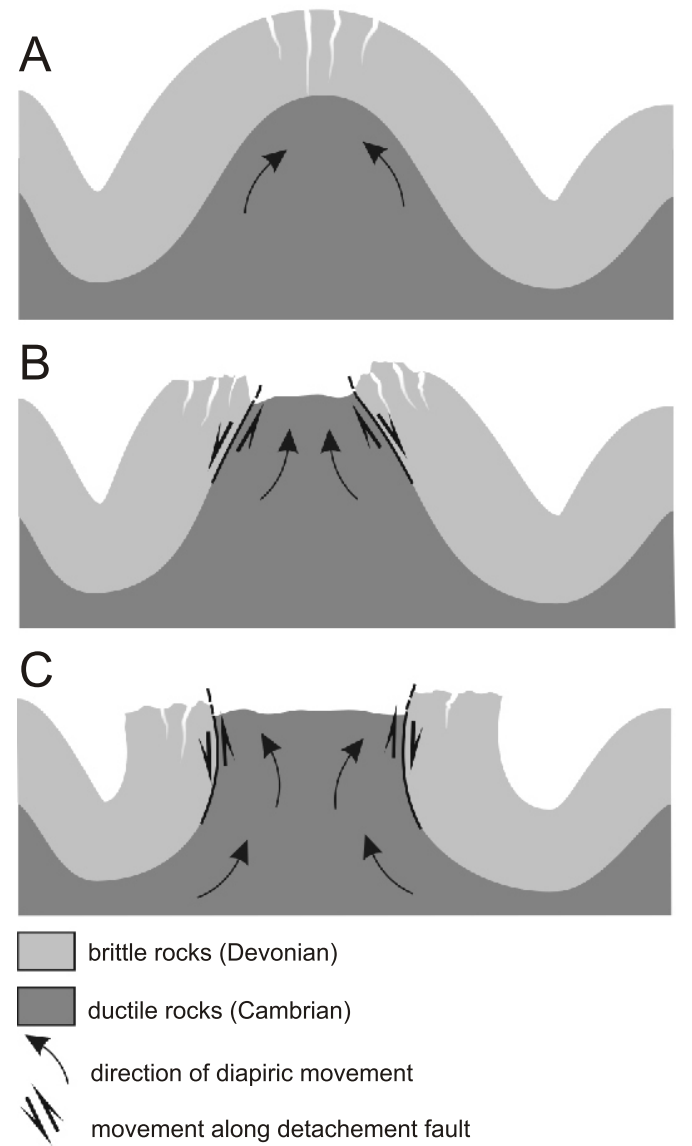

Fig. 1. Chart showing possible structural-geometrical remodelling of the Chęciny Anticline due to diapiric flow of ductile Cambrian strata

A - initial stage; B - development of extensional fractures and concurrent erosion cause release and flow of shales trapped in anticline core and outward movement of anticlinal limbs; $\mathbf{C}$ - continuing erosion causes flow of ductile rocks from syncline hinges towards anticline hinge and may result in overturned strata

(Mastella et al., 2013), marked in their map without scale (fig. 3), does not run through Sosnówka Hill (where the pictures in fig. 2A were taken). Thus locating those pictures in the cross-section is erroneous. According to the original Konon's (2006: fig. 4A) work, this cross-section runs through Zamkowa Hill. Overturned strata on Zelejowa Hill, shown in figure 2C (Mastella et al., 2013), strike $50^{\circ}$ and are oblique to the regional trend. Thus, these strata dips cannot be judged representative, but instead should be considered untrustworthy. Remarkably, they have not been taken into account in Konon's (2006: fig. 4A) cross-section either.

Mastella et al. (2013) suggest diapiric flow while simultaneously questioning it, citing facies variability in the Cambrian and the lack of metamorphism in the Dyminy Anticline. We agree with the argument regarding the Dyminy Anticline, but this region has not been the subject of our work. Regarding the age of diapirism: in the last chapter of our paper we state that "pre-Triassic uncovering of Cambrian rocks could also have been responsible for diapiric-like tectonics". Mastella et al. (2013) erroneously assign to us the suggestion of an Alpine age of this phenomenon.

Mastella et al. (2013) interpret the direction of motion along faults bounding the core of the Chęciny Anticline (Jurewicz and
Stępień, 2012: fig. 7A) as normal faulting but in fact it is a diapiric flow direction, being the result of detachment at competent/incompetent rock interfaces originated in a compressional stress field. The cross-section in Konon (2006: fig. 4A) used by Mastella et al. (2013: fig. 2D) shows listric faults changing updip from normal to reverse. However, in the cross-sections of Konon (2006), Devonian strata are in normal position. We hope that our outline of evolution of the Chęciny Anticline, encompassing diapiric flow of Cambrian, explains overturned strata without the need for multiple faults. The evolutionary model shown in Figure 1 assumes erosion of the anticlinal hinge and limbs concurrent with diapiric flow towards the anticline core, which could have pushing the limbs outwards to the point of overturning the strata.

The present controversy is a good opportunity to revise and correct the geological cross-section through the Kielce Unit based on Filonowicz (1973) and Hakenberg (1973), slightly modified by Konon (2006) - shown by Mastella et al. (2013) in their figure 2D. We propose to incorporate the Wrzosy Anticline into the section and to change the fold geometry from that similar in Konon (2006: fig. 4A) to a concentric fold (Fig. 2). Similar folds do occur locally in the Devonian of the Holy Cross Mts. but exclusively in fine-bedded strata and at the scale of an exposure, not at cross-section scale. The considerable percentage of dolostone and/or massive limestone and shallow deformation argue strongly in favour of concentric fold geometry. Konon's (2006) assumption of similar folds results in a difficulty to explain the increase (by 1/3, what means $170 \mathrm{~m}$ ) in thickness of Devonian strata in the Rzepka Syncline hinge considering the lithologies, this is unlikely. The next change that we propose regards the reverse faults cutting the Cambrian and continuing into the Devonian limbs of the anticline. Konon (2006) based his cross-section on Kowalski's (1975) model, inspired in turn by Sanford's (1959) modelling work. Both Kowalski (1975) and Konon (2006) did not take into account that this modelling does not incorporate a fold nor an important rheological contrast, which is the Cambrian/Devonian boundary. Applying Sanford's faults - developed in flat-lying overburden during block-like deformation of its basement - into a folded structure results in a very small angle between faults and bedding within fold limbs. This brings about two questions: (1) why the slip did not occur instead on either bedding planes or on the detachment between the two contrasting structural levels (competent/incompetent layers); (2) how did reverse faults dipping $80^{\circ}$, presented in Mastella et al. (2013: fig 2D), produced overturned strata dipping at up to 59 (Mastella et al., 2013: fig. 2C)? Konon's (2006) cross-section also needs to be revised to include the Eemsian outcrop uncovered in 1978 during earthworks close to Chęciny (Głazek et al., 1981). The next change involves the Silurian which has been drawn without taking into consideration the structural inheritance rules and the thickness of which increases towards the anticline hinge - while according to Głazek et al. (1981) the Silurian might be missing in this area. The group of faults at the limit between the Paleozoic core and the Mesozoic fringe of the Holy Cross Mts. also needs to be corrected. Two of them, a few tens of metres away from each other, cut incompetent Cambrian rocks. A single fault at the limit between competent and incompetent successions would seem more appropriate here. Likewise, what crops out between these two faults should be clearly marked. The patterns used by Konon (2006) suggest that this is either the Muschelkalk overlying the Cambrian or the over-thick Callovian overlying the over-thick Upper Triassic (see Hakenberg, 1973, 1974). 


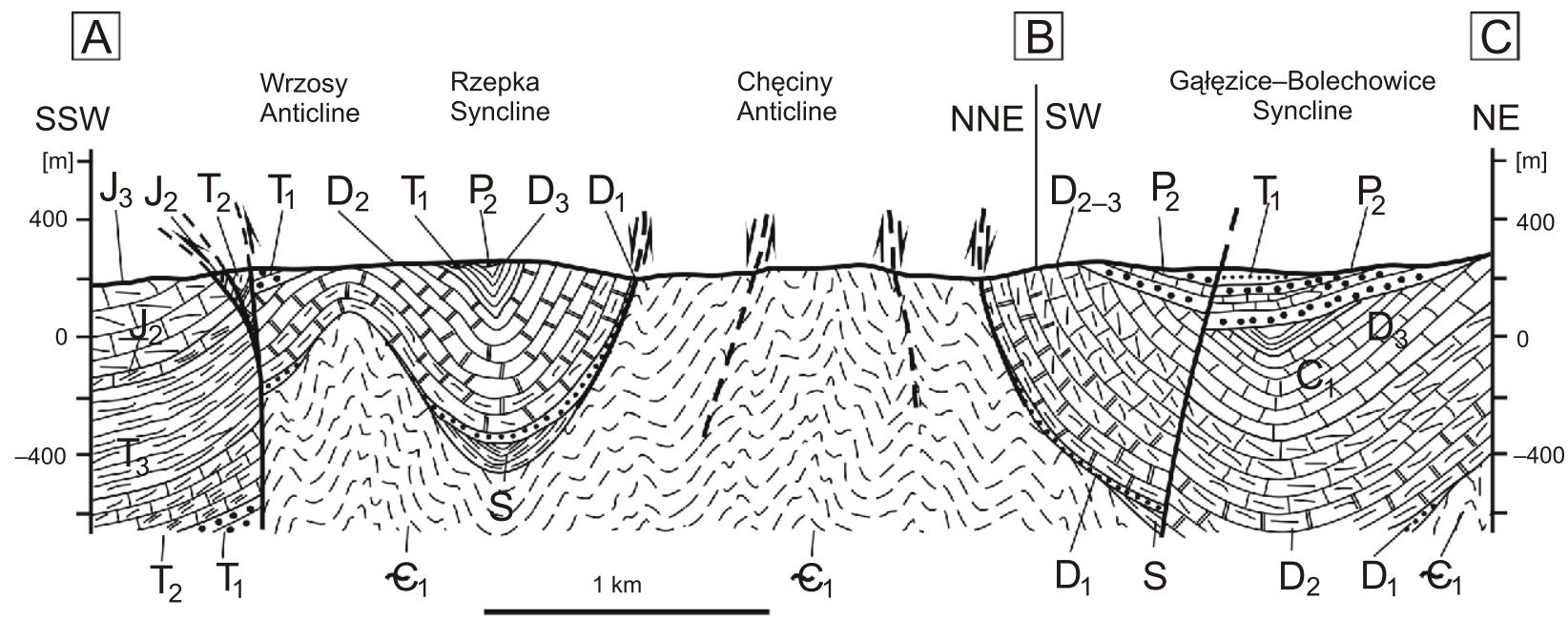

Fig. 2. Geological cross-section through the southern part of the Kielce fold zone based on Filonowicz (1973) and Hakenberg (1973), slightly modified by Konon (2006) and revised by the present authors

$G_{1}$ - Lower Cambrian sandstones and shales; $S$ - Silurian shales; $D_{1}$ - Lower Devonian sandstones; $D_{2}$ - Middle Devonian dolomites and limestones; $D_{3}$ - Upper Devonian limestones and shales; $C_{1}$ - Lower Carboniferous shales; $P_{2}-$ Upper Permian conglomerates and limestones; $T_{1}$ - Lower Triassic sandstones and shales; $T_{2}-$ Middle Triassic limestones; $T_{3}$ - Upper Triassic shales; $J_{2}-$ Middle Jurassic gaizes and shales; $J_{3}$ - Upper Jurassic limestones; for location of the cross-section see Mastella et al. (2013: fig. 3)

\section{AGE AND ORIGIN OF FRACTURES}

A synfolding origin of fractures does not necessarily mean that they were formed in a single episode, simply because growth of the Chęciny Anticline has been a continuous process taking place during the Late Carboniferous (e.g., Czarnocki, 1919, 1957; Lamarche et al., 1999, 2003). We do not contest the age of fractures, defined by Migaszewski et al. (1996) based on lithological-petrological and isotope studies which documented six major phases of calcite mineralization, because we did not conduce such studies ourselves; neither did Konon (2004), cited by Mastella et al. (2013). Konon (2004) only cited his predecessors "The age of this faults/fractures-filling calcite is associated with pre-Permian (Wrzosek and Wróbel, 1961; Rubinowski, 1971) or with somewhat younger Late Carboniferous/Permian (Lewandowski, 1999: fig. 9, cluster 4) and Permian phases of calcite mineralization (Wierzbowski, 1997)". Our work aimed instead to estimate the magnitude of longitudinal extension, assessed by summing up of calcite vein thicknesses.

\section{SECOND-ORDER FOLDS OR SECOND-ORDER FOLD}

In the last chapter of our work we state that "These two structural elements are local, second-order folds that do not continue far towards the NW" and we use such wording in a few other instances, so Mastella et al. (2013) could at best reproach a misspelling or a lack of consistently. In the case that they quote we discuss the rank of the fold, not its geometry. Disputing that the definition of a fold "...a fold is a tectonic structure composed simultaneously from an anticline and a syncline..." as a definition which "...was used many decades ago..." is simply wrong. In, for example, the textbook by Kuzak and aba (2011) this is exactly the definition of a fold.

\section{IS THE DEEP, PRE-TRIASSIC EROSION A DISCOVERY?}

We report in our paper that "New mapping data reveals deep, pre-Triassic erosion of folded Variscan basement, uncovering Cambrian rocks cropping out in the hinge of the Wrzosy Anticline". This means that we demonstrate deep erosion in the area of the Wrzosy Anticline and not that we reinvent observations well-known from the eastern part of the Chęciny Anticline - observations marked by Mastella et al. (2013) by an arrow on the scale-less map (fig. 3). First of all, no one before us (and Czarnocki, 1938; ignored by all) ever documented an anticlinal fold here nor proposed uncovering of Cambrian strata before the Triassic within the area located to the south of the Rzepka and Zamkowa hills. We have added new facts to the already known ones. Mastella et al. (2013) missed the point that the evidence favouring the existence of the Wrzosy Anticline to the south of the Rzepka Syncline resolves the number of geometric-structural problems exemplified even on the (continuously quoted here) cross-section (fig. 2D).

\section{REMARKS REGARDING FIGURE 4 OF THE DISCUSSION PAPER}

Transfer of the fold shape from block 2 to block 4 , as done by Mastella et al. (2013: fig. 4B, C) is unwarranted, because it assumes ideal, constant fold geometry unchanging along its axis. We stressed that "The Rzepka Syncline is a local structure, present only to the south of Zamkowa Hill and at Rzepka and Sosnówka hills. It does not continue towards the NW, where instead several faults, responsible for the complex tectonic structure of Zegzela Hill and ebrownica are present (Kutek and Głazek, 1972)". Cross-cutting of the anticline by transverse faults allowed each block to deform somewhat autonomously during subsequent deformation stages. Figure 4 in 
our paper (Jurewicz and Stępień, 2012) is described as a schematic chart that should facilitate the understanding of our ideas, not as an accurate block diagram enabling throw magnitude estimations of the transverse faults. The anticline itself does not continue to infinity but disappears close to Miedzianka becoming an overturned fold along the way (e.g., Dębowska, 2004). A fold's geometry cannot be reproduced along its entire length by the copy/paste method - especially given the reservations expressed in our work. Konon (2006) also noted that "The geometries of the fold shape profiles also commonly change along their axes. For example, these changes are clearly visible in the Niewachlów and Chęciny Anticlines".

\section{DIGITAL OR NUMERICAL PROCEDURE?}

Photographs shoot with a digital camera were subjected to analysis, the result of which is not an image but a set of numbers obtained by numerical methods, thus the terminology we used appears to be adequate. In tectonics (and other fields of knowledge) DEM (Digital Elevation Model) analysis is widely used. The Polish equivalent of the DEM is "NMT - Numeryczny Model Terenu" (not: "Digitalny") and no one discredits the results based on the "NMTs" simply because of nomenclatural discrepancies.

\section{LACK OF SZANIAWSKI ET AL. (2011) REFERENCE}

The paper by Szaniawski et al. (2011) was published when our work had already been accepted for publication.

\section{ACCURACY OF MEASUREMENTS}

The methods we used for determination of the value of longitudinal extension in this region were deliberately approximate - and we would like to stress that until then no one ever tried to estimate this extension by any method. Available data does not allow taking into account all imaginable variables, but this does not mean that attempts should not be made. We intended to estimate the percentage of longitudinal extension from summed calcite mineralization, not to measure extension with absolute precision. We are conscious that the result of our measurement would be different at different levels of the Rzepka Quarry wall, thus attempting (or pretending) to be over-exact would simply be wrong. Our measurements were only aimed at estimating the scale of the phenomenon and determining its share in longitudinal extension - is it tiny or significant? It is an open question whether the result $=8.4 \%$ means significant or insignificant extension.

Our detailed breccia analyses based on photographs apply to $2.5 \%$ of the quarry wall length. We conducted linear, not areal measurement. Given the subject of our work we were interested mostly in the filling between breccia clasts. The two breccia types occurred separately in various fault zones we did not observe transitions between them.

Many semi-quantitative methods, such as the one applied by us, are widely used in various fields of knowledge, e.g. in biology or medicine but also in petrography or sedimentology (granulometry) - always keeping in mind that the results are approximate but at the same time significant. All of structural geology is based on approximate measurements, starting with measurements of bedding surfaces, which never are ideal planes. The precision of the method we used is comparable to the precision of other methods used in structural geology, e.g. to the measurements of fracture density (Paduszyński, 1965; Mastella, 1972) or to measuring joint attitudes with help of a cuboid. The advantages of our method are its simplicity, negligible cost and the applicability to other quarry walls, which are oriented longitudinally with respect to structure strikes. Questioning the comparison of the magnitude of extension with the magnitude of shortening estimated in Hakenberg's (1973) unbalanced cross-section show that there is still a lot of work to be done in the Holy Cross Mountains. We hope that this observation will become inspiration for further geological and geophysical field research and will advance understanding of the Holy Cross Mts.' geology.

\section{REFERENCES}

Czarnocki J. (1919) Stratygrafia i tektonika Gór Świętokrzyskich. Prace Towarzystwa Naukowego Warszawskiego, 28.

Czarnocki J. (1938) Carte géologique générale de la Pologne, scale 1:100,000, feuille 4, Kielce. Edition du Service Géologique de Pologne.

Czarnocki J. (1957) Tectonics of the Święty Krzy Mountains (in Polish with English summary). Prace Instytutu Geologicznego, 18: $11-138$.

Dębowska U. (2004) Some aspects of tectonics and mineralization in the Devonian rocks in the western part of the Chęciny Anticline: Miedzianka Mt., NW part of the Holy Cross Mts., central Poland (in Polish with English summary). Przegląd Geologiczny, 52 (9): 920-927.

Filonowicz P. (1973) Szczegółowa mapa geologiczna Polski w skali 1:50 000, arkusz Kielce. Wydawnictwa Geologiczne, Warszawa.

Filonowicz P., Lindner L. (1986) Szczegółowa mapa geologiczna Polski w skali 1:50 000, arkusz Piekoszów. Wydawnictwa Geologiczne, Warszawa.
Filonowicz P., Lindner L. (1987) Objaśnienia do Szczegółowe mapy geologicznej Polski w skali 1:50 000, arkusz Piekoszów. Wydawnictwa Geologiczne, Warszawa.

Głazek J., Karwowski Ł., Racki G., Wrzołek T. (1981) The Early Devonian continental/marine succession at Chęciny in the Holy Cross Mts. and its paleogeographic and tectonic significance. Acta Geologica Polonica, 31: 233-250.

Hakenberg M. (1973) Szczegółowa mapa geologiczna Polski w skali 1:50 000, arkusz Chęciny. Wydawnictwa Geologiczne, Warszawa.

Hakenberg M. (1974) Objaśnienia do Szczegółowej mapy geologicznej Polski w skali 1:50 000 arkusz Chęciny. Wydawnictwa Geologiczne, Warszawa.

Jurewicz E., Stępień U. (2012) Tectonics of the Chęciny Anticline (Holy Cross Mts., Central Poland) in the light of new cartographic data and calcite vein analysis. Geological Quarterly, $\mathbf{5 6}$ (1): 95-106.

Konon A. (2004) Successive episodes of normal faulting and fracturing resulting from progressive extension during the uplift of 
the Holy Cross Mountains, Poland. Journal of Structural Geology, 26: 419-433.

Konon A. (2006) Buckle folding in the Kielce Unit, Holy Cross Mountains, central Poland. Acta Geologica Polonica, 56: 375-405.

Kotański Z. (1959) Przewodnik geologiczny po Górach Świętokrzyskich. Wydawnictwa Geologiczne, Warszawa.

Kowalski W.R. (1975) Tectonics of western end of Chęciny Anticline and surrounding structures of Mesozoic margins of the Holy Cross Mts. Rocznik Polskiego Towarzystwa Geologicznego, 45: 45-61.

Kutek J., Głazek J. (1972) The Holy Cross area, Central Poland, in the Alpine cycle. Acta Geologica Polonica, 22: 603-653.

Kuzak R., aba J. (2011) Podstawy geologii strukturalnej. Struktury fałdowe. Wydawnictwo Naukowe PWN

Lamarche J., Mansy J.L., Bergerat F., Averbuch O., Hakenberg M., Lewandowski M., Stupnicka E., Świdrowska J., Wajsprych B., Wieczorek J. (1999) Variscan tectonics in the Holy Cross Mountains (Poland) and the role of structural inheritance during Alpine tectonics. Tectonophysics, 313: 171-186.

Lamarche J., Lewandowski M., Mansy J.L., Szulczewski M. (2003) Partitioning pre-, syn- and post-Variscan deformation in the Holy Cross Mountains, eastern Variscan foreland. Geological Society Special Publication, 208: 159-184.

Lewandowski M. (1999) A palaeomagnetic study of fracture fills in the Holy Cross Mountains of Central Poland and its application in dating tectonic processes. Geophysical Journal International, 137: 783-792.

Mastella L. (1972) Interdependence of joint density and thickness of layers in the Podhale flysch. Bulletin de l'Académie Polonaise des Sciences, Série des Sciences de la Terre, 20: 187-196.

Mastella L., Konon A., Dwornik M., Ludwiniak M., Rybak-Ostrowska B., Śmigielski M. (2013) Tectonics of the
Chęciny Anticline (Holy Cross Mts., central Poland) in the light of new cartographic data and calcite vein analysis (discussion). Geological Quarterly, 57 (1): 175-180.

Migaszewski M.Z., Hałas S., Durakiewicz T. (1996) The age and origin of the calcite mineralization in the Holy Cross Mts. based on lithologic-petrographic and isotopic evidence (in Polish with English summary). Przegląd Geologiczny, 44 (3): 275-281.

Paduszyński J. (1965) Szacowanie gęstości mikroszczelin metodą trawersów losowych. Nafta, 1: 2-3.

Rubinowski Z. (1971) The non-ferrous metal ores of the Świętokrzyskie Mountains and their metallogenic position (in Polish with English summary). Biuletyn Instytutu Geologicznego, 247: 8-166.

Sanford A.R. (1959) Analytical and experimental study of simple geologic structures. Geological Society of America Bulletin, 70: 19-51.

Stewart S.A. (1996) Influence of detachment layer thickness on style of thin-skinned shortering. Journal of Structural Geology, 18: $1271-1274$.

Szaniawski R., Konon A., Grabowski J., Schnabl P. (2011) Palaeomagnetic age constraints on folding and faulting events in Devonian carbonates of the Kielce fold zone (southern Holy Cross Mountains, Central Poland). Geological Quarterly, 55 (3): 223-234.

Wierzbowski H. (1997) Buntsandstein in the karst infillings at Chęciny (Holy Cross Mts., Central Poland) and its significance for regional geological considerations (in Polish with English summary). Przegląd Geologiczny, 45 (7): 707-710.

Wrzosek J., Wróbel L. (1961) Notes on the occurrence of calcite veins on Zelejowa Mountain near Chęciny (in Polish with English summary). Zeszyty Naukowe AGH w Krakowie, Geologia, 31: 89-106. 